\title{
Unproportional Health Services in Hospitals for Third Class BPJS Kesehatan Participant
}

\author{
Galih Endradita $^{1 *}$, Ahmad Yudianto $^{2}$, Muhammad Afiful Jauhani ${ }^{1}$ \\ ${ }^{1}$ A resident of Forensic Medicine and Medicolegal Specialist Program, Faculty of Medicine, Universitas Airlangga, \\ Indonesia \\ ${ }^{2}$ Department of Forensic Medicine and Medicolegal, Universitas Airlangga - dr. Soetomo General Hospital, Indonesia \\ *Corresponding Author. Email: galihendradita@gmail.com
}

\begin{abstract}
BPJS is a legal entity formed to carry out social security programs by Law Number 24 of 2011 regarding Social Security Administrator. BPJS Kesehatan services divided by class according to the non-medical benefits of participation in Presidential Regulation Number 82 of 2018 regarding Health Insurance. The 3rd class membership services constitute the majority and require hospital preparedness. The reality is that the majority of Indonesian people are registered as BPJS Kesehatan 3rd class participants, but contradictively the Minister of Health Regulation Number 56 of 2014 regarding Classification And Licensing of Hospital only allocates at least $30 \%$ hospital beds for $3^{\text {rd }}$ class BPJS Kesehatan participant, so that many 3rd class BPJS Kesehatan participants are not accommodated according to their service class. Even though The Regulation of the Minister of Health of The Republic of Indonesia Number 85 of 2015 Concerning National Hospital Rates Scheme, $3^{\text {rd }}$ class BPJS Kesehatan participant hospital rates are set under the break-even point. This paper identifies socio-legal problems and analyzes problems using a conceptual approach related to the implementation of the law. There is a gap between the facts and the regulations made by the ministry of health-related to hospital services for patients in $3^{\text {rd }}$ class BPJS Kesehatan participants. $3^{\text {rd }}$ class, BPJS Kesehatan participants is difficult in obtaining facilities due to the limited allocation of hospital beds. The losses because the hospital rate guidelines for 3rd class BPJS Kesehatan participants are set below the break event point even though the majority of hospital customers are $3{ }^{\text {rd }}$ class BPJS Kesehatan participants. Patients as 3rd class BPJS Kesehatan participants receive unproportional health services in hospitals due to gaps in the Ministry of Health regulation. Ministry of Health must improve regulations related to hospital services for 3rd class BPJS Kesehatan participants by increasing the minimum allocation of the number of hospital beds and hospital service rates for 3rd class BPJS Kesehatan participant.
\end{abstract}

Keywords: BPJS Kesehatan, unproportional, health services, hospital

\section{INTRODUCTION}

According to Law Number 36 of 2009, health is a state of physical health, mental, spiritual and social that enables everyone to live productively, socially, and economically. Everyone has the right to the highest attainable standard of physical and mental health. Health services carried out are efforts to maintain and improve the health status of the community as high and carried out based on nonprovincial principles. Discriminatory, participatory and sustainable in the context of the formation of Indonesian human resources. Health Development is carried out based on humanity, balance, benefits, protection, respect for rights and obligations, justice, gender and nondiscrimination, and religious norms [1]. According to Law Number 24 of 2011 concerning the Social Security Organizing Agency, BPJS Kesehatan is a form of a state program that aims to provide certainty of protection and social welfare for all Indonesian people [2]. Social security in the health sector through Presidential Regulation Number 19 of 2016 The second amendment to Presidential Regulation Number 12 of 2013 concerning Health Insurance explains the guarantee in the form of health protection so that participants receive health care benefits and protection in meeting basic health needs given to everyone who has paid contributions or whose fees have been paid by the government.

\section{METHOD}

This paper identifies socio-legal problems and the problems analyzed with a conceptual approach related to the implementation of the law. This study based on data from BPJS Kesehatan and recapitulation of patient visit reports by Pelengkap Medical Center Hospital from August 2018 to July 2019. 


\section{RESULTS AND DISCUSSION}

BPJS Kesehatan participants have continued to increase from 2017 to 31 August 2019, and dominated by $3^{\text {rd }}$ class participants totaling 128 million or $68.28 \%$ in 2017 , then increased to 141 million or $68.24 \%$ in 2018 , and 153 million or $66.47 \%$ in 2019.

Table 1. Percentage of BPJS participants from 2017 to August 21 in 2019

\begin{tabular}{|l|l|l|l|l|l|l|}
\hline & \multicolumn{2}{l}{2017} & 2018 & \multicolumn{2}{l|}{2019} \\
\hline 1st & & 12, & & 12, & & 12, \\
Clas & 23.412. & 45 & 25.696. & 35 & 27.650. & 00 \\
s & 752 & $\%$ & 561 & $\%$ & 156 & $\%$ \\
\hline 2nd & & 19, & & 19, & & 21, \\
Clas & 36.224. & 27 & 40.382. & 41 & 49.584. & 53 \\
s & 403 & $\%$ & 404 & $\%$ & 562 & $\%$ \\
\hline 3rd & & 68, & & 68, & & 66 \\
Clas & 128.34 & 28 & 141.97 & 24 & 153.09 & 47 \\
s & 5.974 & $\%$ & 5.234 & $\%$ & 9.396 & $\%$ \\
\hline & 187.98 & & 208.05 & & 230.33 & \\
& 3.129 & & 4.199 & & 4.114 & \\
\hline
\end{tabular}

Source: BPJS Kesehatan, August 31, 2019 (3)

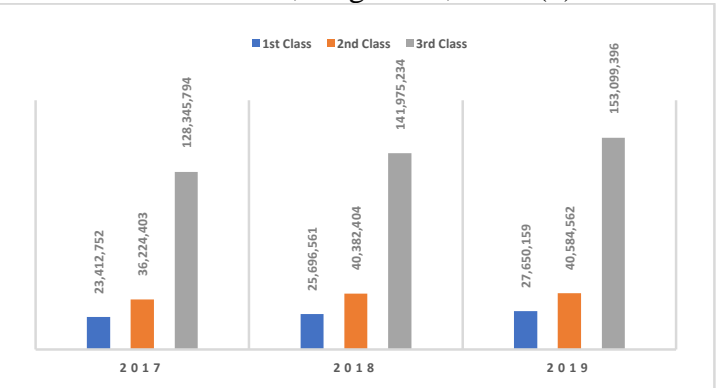

Figure 1. Growth of BPJS Kesehatan Participation in 2017 until August 21 in 2019

Figure 1 shows the growth of BPJS Kesehatan membership dominated by the growth of $3^{\text {rd }}$ class participants. $1^{\text {st }}$ class and $2^{\text {nd }}$ class BPJS Kesehatan participants tend to be constant.

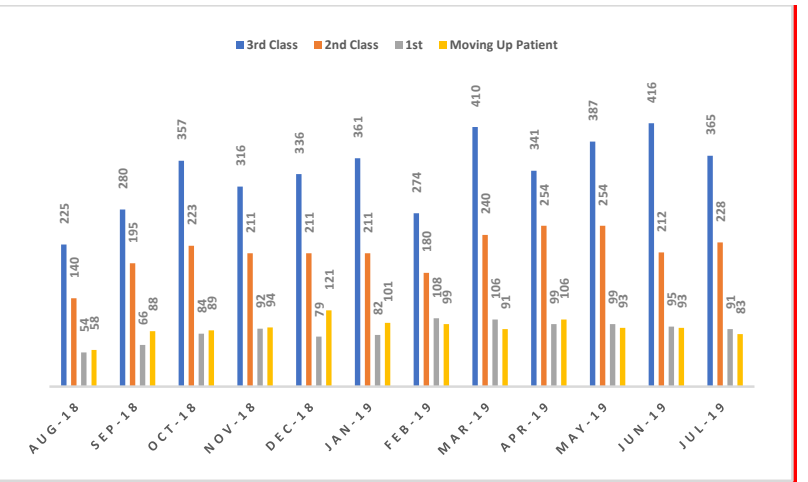

Figure 2. Pelengkap Medical Center Hospital Inpatient Growth of BPJS Kesehatan From August 2018 until
July 2019 (4)

Figure 2 shows most inpatient hospital visits in Pelengkap Medical Center Hospital in Jombang were $3^{\text {rd }}$ class.

\section{DISCUSSION}

\section{A. Distribution of BPJS Kesehatan Participation Classes}

Presidential Regulation Number 82 the Year 2018 Article 28 states that the Indonesian government and regional governments pay contributions from PBI participants (recipient of contribution assistance). PBI participants are categorized as BPJS Kesehatan $3^{\text {rd }}$ Class participants. $1^{\text {st }}$ class and $2^{\text {nd }}$ class BPJS Kesehatan participants consisting of civil servants and private employees. Each participant is entitled to obtain health insurance benefits that are individual health services, including promotive, curative, and rehabilitative services, including drug services, medical devices, and consumable medical materials according to medical needs that are needed. [5]

Benefits are divided into medical benefits and non-medical benefits. Medical benefits are following medical indications and service standards. Non-medical benefits are based on participant contributions. [5]

\section{B. Determination of Hospital Rates}

Hospital rate refers to the Minister of Health Regulation No. 85 the Year 2015 concerning the National Hospital Hospital Rate Regulation is a reward received by the hospital for services from service activities provided to service users. The national hospital rate pattern is determined based on the unit cost component and takes into account regional conditions. Rates at the hospital are divided into [6]

1. Components of facilities and outpatient services

2. Inpatient services component

3. Emergency services component

Minister of Health Regulation Number 85 the Year 2015 states that outpatient hospital rate calculations can be divided into:

1. Regular outpatient services are determined according to the break-even point;

2. Non-regular outpatient services are determined to be greater than regular outpatient services with the amount determined based on the principle of propriety.

Calculation of inpatient rates are distinguished based on the class of care with the following conditions:

1. $3^{\text {rd }}$ Class rates are determined to be smaller than $2^{\text {nd }}$ Class;

2. $2^{\text {nd }}$ Class rates are determined according to the break-even point;

3. Rates for $1^{\text {st }}$ class and are determined more than $2^{\text {nd }}$ class with the amount determined based on the principle of propriety

Calculation of emergency care rates is set greater than the break-even point with the amount determined based on the principle of propriety.

Break-Even Points is the position of income and costs are equal or balanced so that there are no profits or losses in a hospital (company). Break-even points are used to analyze 
the extent of the amount of service produced to get a breakeven or return on capital. [7]

The formula used to calculate break-even points is the number of goods/services that must be produced to get a break-even point $=\mathrm{FC} /(\mathrm{P}-\mathrm{VC})$

$\mathrm{FC} \quad=$ Fixed Cost

$\mathrm{P} \quad=$ Selling Price

$\mathrm{VC}=$ Variable Cost

From the description above it can be concluded that hospitals that conduct health services to $3^{\text {rd }}$ class BPJS Kesehatan participants suffer losses due to financing claims obtained below the break-even point (8)

\section{The proportion of Services at the Hospital}

Minister of Health Regulation No. 56 of 2014 concerning classification and licensing of hospitals article 20,31, 42, and article 52 in class A, B, C and D hospitals that have been updated through Minister of Health Regulation No. 30 of 2019 concerning Classification and Licensing of Hospital Article 44 does not change the provisions regarding the percentage of minimum number of $3^{\text {rd }}$ class bed facilities:(9)

a. Number of $3^{\text {rd }}$ class bed facilities at least $30 \%$ (thirty percent) of all beds for government hospitals.

b. The number of $3^{\text {rd }}$ class bed facilities is at least $20 \%$ (twenty percent) of all beds for privately owned hospitals.

\section{Inpatient JKN Services Moving Up Class}

The Government through the Minister of Health Regulation Number 4 of 2017 concerning the Second Amendment to the Minister of Health Regulation Number 52 of 2016 concerning Health Service Standards in the Implementation of the Health Insurance Program Article 25 mentions: (10)

1. Moving up in inpatient service class from $3^{\text {rd }}$ class to $2^{\text {nd }}$ class, from $3^{\text {rd }}$ class to $1^{\text {st }}$ class, and from $2^{\text {nd }}$ class to $1^{\text {st }}$ class, must pay the cost difference between the INA-CBG hospital rate for the higher inpatient class selected with the INA-CBG rate in the inpatient class that matches the participant's claims;

2. For upgrading inpatient services to VIP classes with facilities 1 (one) level above $1^{\text {st }}$ class, additional payment fees are determined as follows :

1. Moving from $1^{\text {st }}$ class to VIP class, the additional payment of a fee of no more than $75 \%$ of the INA-CBG $1^{\text {st }}$ class hospital rate;

2. Moving up from $2^{\text {nd }}$ class to VIP class is the difference between INA-CBG $1^{\text {st }}$ class tariff and INA CBG $2^{\text {nd }}$ class hospital rate plus the additional payment from $1^{\text {st }}$ class to VIP class at a maximum of $75 \%$ of INA-CBG for $1^{\text {st }}$ class hospital rate; and

3. Moving up from $3^{\text {rd }}$ class to VIP class is the difference in INA-CBG $1^{\text {st }}$ class hospital rate with INA-CBG $3^{\text {rd }}$ class hospital rate plus the additional payment from $1^{\text {st }}$ class to VIP at a maximum of $75 \%$ of INA-CBG $1^{\text {st }}$ class hospital rate.

The proportion of $3^{\text {rd }}$ class beds in patients who reasoned to remain in the hospital was forced to graduate so that $3^{\text {rd }}$ class patients who have a lower middle class must pay more to get health services in the hospital.

\section{CONCLUSION}

Unproportional health services for $3^{\text {rd }}$ class BPJS kesehatan participant is triggered by the incongruity between bed allocation in hospitals and the proportion of $3^{\text {rd }}$ class BPJS Kesehatan participants. BPJS Kesehatan $3^{\text {rd }}$ class participants are $60 \%$ from total BPJS Kesehatan participants and have the highest number of visits, but the availability of beds in the hospital is only $30 \%$ then forced to move to $2^{\text {nd }}$ class service. As a result, the cost of health services increased for patients and BPJS Kesehatan. Patients have to spend money on moving and get services at a higher hospital class. Hospitals are forced to provide BPJS Kesehatan services in $3^{\text {rd }}$ class, thereby threatening the financial stability of the hospital due to having to provide financial compensation below the break-even point. Based on this study, we propose an amendment to the Minister of Health Regulation Number 30 of 2019 concerning Hospital Classification and Licensing Article 44. This study is a preliminary study and further studies are expected to be carried out to improve the service of BPJS Kesehatan $3^{\text {rd }}$ Class patients while reducing costs incurred by BPJS Kesehatan in $3^{\text {rd }}$ class patient services

\section{ACKNOWLEDGMENT}

We would thank Prof. DR. dr. Fahmi Idris, M.Kes as Executive Director (ED) BPJS kesehatan.

\section{REFERENCES}

[1] Presiden Republik Indonesia. Undang Undang Nomor 36 Tahun 2009 tentang Kesehatan. 2009. 31-47 p.

[2] Presiden Republik Indonesia. Undang Undang Nomor 24 Tahun 2011 tentang Badan Penyelenggara Jaminan Sosial. Kementrian Sekretrariat Negara RI. Jakarta: Kementrian Sekretariat Negara RI; 2011. 53 p.

[3] BPJS Kesehatan. Data Kepesertaan BPJS Kesehatan.pdf. Jakarta; 2019.

[4] RSU Pelengkap Medikal Center. Grafik Kunjungan Per Kelas Pelayanan Rawat Inap RSU Pelengkap Medikal Center Jombang. Jombang; 2019.

[5] Pemerintah Republik Indonesia. Peraturan Presiden Nomor 82 Tahun 2018 tentang Jaminan Kesehatan. 2018.

[6] Kementrian Kesehatan. Pola Tarif Nasional Rumah Sakit. Vol. 13, Kementrian Kesehatan. Jakarta; 2015. 1576-1580 p.

[7] Malan I, Mohammad Aryo A, Titin S. Analisa Break Even Point dalam menentukan harga pokok sewa kamar pada RSUD Sekayu. J Account Politek Sekayu. 2018;VII:23. 
[8] Woolf SH, Johnson RE. The break-even point: When medical advances are less important than improving the fidelity with which they are delivered. Annals of Family Medicine. 2005.

[9] Menteri Kesehatan. Peraturan Menteri Kesehatan Republik Indonesia Nomor 30 Tahun 2019 tentang Klasifikasi dan perijinan Rumah Sakit. 2019;23(3):1-19.

[10] Direktorat Pelayanan BPJS Kesehatan. Administrasi Klaim Fasilitas Kesehatan BPJS Kesehatan. BPJS Kesehat. 2018;7-29. 